\title{
INCIDENCE OF REFLEX SYMPATHETIC DYSTROPHY OF THE UPPER EXTREMITY SHOULDER-HAND SYNDROME
}

\author{
BY \\ VEIKKO A. I. LAINE \\ Heinola, Finland
}

(RECEIVED FOR PUBLICATION JULY 20, 1953)

According to the large literature on the subject, the reflex sympathetic dystrophy of the upper extremity, or so-called shoulder-hand syndrome (Steinbrocker, 1947), seems to be relatively common. Unfortunately the literature contains no data about the incidence of this disorder as a whole. Many authors have reported its incidence to be 10-20 per cent. of cases of coronary occlusion (Askey, 1941 ; Johnson, 1943; Järvinen, 1952). Meyer and Biswanger (1942) found it in 39 out of 178 consecutive cases of myocardial infarction. Steinbrocker and others (1948) found an idiopathic shoulder-hand syndrome in six out of 250 cases of painful shoulder.

The aetiology is rather complicated, and several factors have been mentioned, including coronary occlusion (Askey, 1941; Johnson, 1943), trauma (Sudeck, 1902; Leriche, 1937; Nissen-Lie, 1951; Moberg, 1951), spondylosis of the cervical spine (Oppenheimer, 1945), and infections. The aetiology of the so-called idiopathic shoulder-hand syndrome is obscure (Steinbrocker, 1947). All these factors are able to produce the disorder either alone or in various combinations.

According to the even more extensive literature, the "painful shoulder" is also very common, a fact which is confirmed by the experience of the general practitioner.

\section{Material and Methods}

To illustrate the incidence of reflex sympathetic dystrophy of the upper extremity, patients attending the out-patient clinic at the Rheumatism Hospital in Heinola was examined, and all cases of painful shoulder and cases with signs of reflex sympathetic dystrophy in the arm were noted.

Altogether 125 patients were selected, and among them were 23 cases $(18.4$ per cent.) with clearly noticeable signs of reflex dystrophy.

The distribution by age, sex, and (in the 23 cases with reflex dystrophy) by side affected is shown in the Table.

\section{Aetiological Factors}

(1) The coronary vessels were affected in four cases.

(2) Osteo-arthrosis of the cervical spine was present to such an extent as to present a possible cause in thirteen cases.

(3) There was a history of preceding trauma in five cases, but in two this was mild and presumably not the cause of disease.

(4) No probable aetiological factors were to be found in four cases in which the diagnosis was idiopathic shoulder-hand syndrome. The proportion of this group to the whole seems to be identical with that found by Steinbrocker.

In one case there have been three subsequent onsets of the disease. This case is one of the group with a history of preceding trauma, and because of its illustrative nature it is reported in detail below.

\section{Case Report}

A 77-year-old married female, in 1948 fell on a staircase and injured her back. During the next few weeks, pain, swelling, and limitation of movement developed in the

TABLE

DISTRIBUTION OF CASES OF PAINFUL SHOULDER BY AGE, SEX, AND SIDE AFFECTED

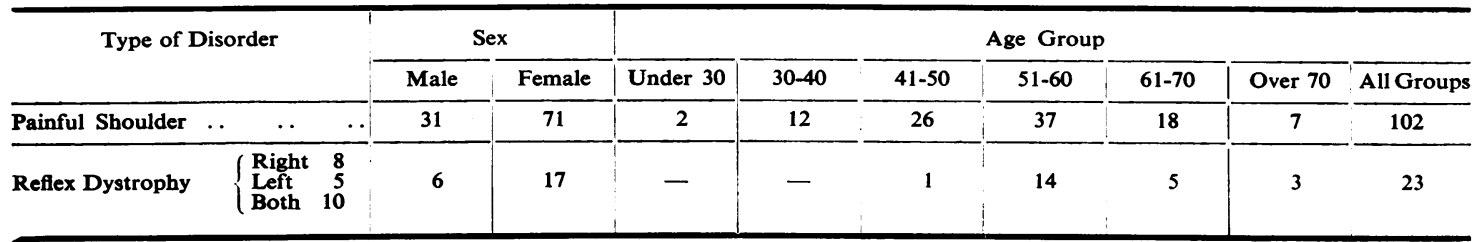


joints of both lower extremities. She was treated for rheumatoid arthritis, the symptoms subsided within a few months, and complete restoration to normal was achieved.

In 1950 she fell again and was admitted to hospital with a broken femur. No signs of reflex dystrophy developed. During her stay in hospital she developed an acute cholecystitis and was operated on. A few days later, still during her stay in hospital, she developed a typical reflex dystrophy syndrome in the right upper extremity. She was treated with physiotherapy, and in a few months was restored to normal health, with full range of motion in the affected extremity, and no signs of trophic disturbance.

In 1951 she fell again and hurt her left wrist. This was placed in plaster, although there were no signs of fracture. A typical reflex dystrophy developed in the left upper extremity.

When she was last seen in the autumn of 1952, she had severe pain in the hand of causalgic type, with solid swelling of the fingers, hand, and wrist, and limitation of movement in all joints in the hand.

$X$-ray examination showed marked bone atrophy in the left hand, and slight atrophy in the right. Erythrocyte sedimentation rate $10 \mathrm{~mm}$. Blood-pressure 200/110 mm. Hg.

Marked sclerosis in all palpable arteries. Electrocardiogram showed cardiosclerosis.

\section{Summary}

(1) 125 cases of painful shoulder were studied. Of these, 23 (18.4 per cent.) showed typical signs of sympathetic reflex dystrophy of the upper extremity.

(2) These cases of reflex dystrophy came from the older age groups, but the peak of incidence in both types of disorder came in the 51 to 60 year group.

(3) The sex incidence in both types of disorder was about equal (one male to $2 \cdot 3$ females in cases of painful shoulder; and one male to $2 \cdot 8$ females in cases of reflex dystrophy).

(4) Regarding the possible aetiology of the disorder, there were four cases of reflex dystrophy associated with cardiac complication, thirteen with osteo-arthrosis of the cervical spine, and three with trauma. In four cases no aetiological factors were to be found and the diagnosis of idiopathic shoulderhand syndrome was made.

(5) In one case reported in detail, there were three subsequent onsets of reflex dystrophy during a 3-year follow-up.

\section{REFERENCES}

Askey, J. M. (1941). Amer. Heart J., 22, 1. Johnson, A. C. (1943). Ann. intern. Med., 19, 433. Jărvinen, K. A. J. (1952). Schweiz. méd.'Wschr., 82, 618. Leriche, R. (1937). Presse méd., 45, 873.
Meyer, J. C., and Biswanger, H. F. (1942). Amer. Heart J., 23, 715. Moberg, E. (1951). "Transactions of the 25th meeting of the Northern Surgical Association", ed. E. Dahl-Iversen, p. 33. Munksgaard Copenhagen.

Nissen-Lie, H. (1951). Ibid., p. 67.

Oppenheimer, A. (1945). Amer. J. Roentgenol., 53, 348.

Steinbrocker, O. (1947). Amer. J. Med., 3, 402. $29,22$.

Sudeck, P. (1902). Dtsch. med. Wschr. (Vereins-Beilage), 28, 170.

Fréquence de la dystrophie sympathique reflexe de l'extrémité supérieure

(Syndrome "Epaule-main")

RÉSUMÉ

(1) On a étudié 125 cas d'épaule douloureuse. Sur ce nombre, $23(18,4$ pour cent.) ont manifesté des signes $\vec{\omega}$ typiques de dystrophie sympathique reflexe du membreo supérieur.

(2) Ces cas de dystrophie reflexe se trouvaient parmiō. les personnes âgées, mais la fréquence maxima des deux $\vec{N}$ formes morbides se trouvait entre l'âge de 51 et 60 .

(3) La distribution entre les deux sexes était à peu près égale dans les deux formes (un homme sur 2,3 femmes $\vec{G}$ pour l'épaule douloureuse et un sur 2,8 pour la dystrophie
reflexe).

(4) Parmi les données éclairant l'étiologie probablede la dystrophie on a trouvé que le coeur était atteint $\square$ dans 4 cas, il y avait une osteoarthrite cervicale dans 13 cas et un antécédent traumatique dans trois cas. $\mathbb{Q}$ Dans 4 cas on n'a pas trouvé de facteur étiologique et on a fait le diagnostic de syndrome "épaule-main" idiopathique.

(5) Dans un cas suivi pendant trois ans et rappoféco ici minutieusement on a observé ultérieurement tr. attaques de dystrophie reflexe.

\section{Incidencia de la distrofia simpática refleja de la extremidad superior \\ (Síndrome "hombro-mano") SUMARIO}

(1) Se estudió 125 casos de hombro doloroso. Manifestaciones típicas de distrofia simpática refleja del miembro superior fueron encontradas en $23(18,4$ por? ciento) de ellos.

(2) Estos casos de distrofia refleja procedieron de grupo de edad avanzada pero la mayor incidencia de embos tipos de disturbio encontrose en el sexto decenio.

(3) En ambos tipos de disturbio la incidencia según 3 el sexo fué aproximadamente igual (un hombre poi: 2,3 mujeres en casos de hombro doloroso y un poró 2,8 en casos de distrofia refleja).

(4) Respecto a la etiología probable del disturbio 0 hubo 4 casos de distrofia refleja asociados con unacomplicación cardiaca, 13 con una ósteoartritis cervica y 3 con un traumatismo. Ningún factor etiológico fuê encontrado en 4 casos y se hizo el diagnóstico de síndrome "hombro-mano" idiopático.

(5) En un caso, relatado detalladamente, hubo tres ataques subsiguientes de distrofia refleja durante treso años de observación. 